\title{
MOLECULAR DIFFERENTIATION OF TRANSMISSIBLE GASTROENTERITIS VIRUS AND PORCINE RESPIRATORY CORONAVIRUS STRAINS
}

\section{Correlation with Antigenicity and Pathogenicity}

\author{
D. J. Jackwood, H. M. Kwon, and L. J. Saif \\ Food Animal Health Research Program \\ The Ohio Agricultural Research and Development Center \\ The Ohio State University \\ Wooster, Ohio 44691
}

\begin{abstract}
Transmissible gastroenteritis virus (TGEV) causes an economically important enteric disease of swine. Differences in the pathogenicity, antigenicity and tissue tropism have been observed among porcine coronaviruses. Although porcine respiratory coronavirus (PRCV) is antigenically similar but not identical to TGEV isolates, these respiratory coronaviruses differ markedly in pathogenicity and tissue tropism compared to TGEV isolates. Using a reverse transcriptase/polymerase chain reaction-restriction fragment length polymorphism (RT/PCR-RFLP) assay, TGEV and PRCV isolates were assigned to several distinct groups. By RFLP analysis of the 5' region of the S gene, TGEV strains were differentiated into 4 groups using the restriction enzyme Sau3AI. A fifth Sau3AI group contained the PRCV isolates. These 5 groups correlated with antigenic groups previously defined using monoclonal antibodies in our laboratory. Several restriction enzymes could be used to differentiate the TGEV strains into Miller and Purdue types. Analysis of a PCR amplified product in the 3 and 3-1 genes indicated the RT/PCR-RFLP assay results for TGEV Miller strains could be correlated with lower virulence created by passage in cell culture.
\end{abstract}

\section{INTRODUCTION}

The antigenicity, pathogenicity and tissue tropism vary among the porcine coronaviruses, transmissible gastroenteritis virus (TGEV) and porcine respiratory coronavirus (PRCV). Pathogenic differences among TGEV isolates have been documented ${ }^{1,2,3,4}$. The 
molecular basis for virulence and tissue tropism was reported to reside in the region of RNA $3 / 3-1^{2,4}$ and in the region of the $S$ glycoprotein gene $e^{5,6,7}$, respectively. Britton et al. ${ }^{2}$ reported that a deletion in RNA 3/3-1 (ORF-3a/3b) was observed in the attenuated TGEV strain 188-SG but not in the virulent D-52 strain of TGEV. Wesley et al. ${ }^{4}$ reported that a similar deletion in RNAs 3/3-1 and 4 was present in an attenuated small-plaque variant of TGEV.

Certain MAbs to TGEV have been used to demonstrate antigenic differences among TGEV and PRCV strains $8,9,10,11,12,13$. Mabs directed to a non-neutralizing epitope on the S glycoprotein of TGEV designated site $\mathrm{B}^{8}$ or site $\mathrm{D}^{9,12,13}$ did not bind to PRCV isolates but did identify TGEV strains. A panel of 12 MAbs generated against the virulent Miller TGEV strain was used to demonstrate differences in antigenicity among TGEV isolates ${ }^{12,13,1415,16}$. Five non-neutralizing MAbs were directed against the N protein and 4 neutralizing MAbs were directed against the $\mathrm{S}$ glycoprotein ${ }^{12,13,14}$. The neutralizing MAbs had different titers against heterologous (Purdue) and homologous (Miller) strains of TGEV indicating variability among these epitopes.

Differences in the tissue tropism of TGEV and PRCV isolates have been extensively characterized $^{7,17,18,19,20,21}$. Molecular differences in the $\mathrm{S}$ glycoprotein gene appear to affect the tissue tropism of these viruses ${ }^{7,17}$.

This study was initiated to determine if molecular differences observed using the reverse transcriptase/polymerase chain reaction-restriction fragment length polymorphism (RT/PCR-RFLP) assay could be correlated with differences in antigenicity, pathogenicity and tissue tropism among TGEV and PRCV viruses.

\section{MATERIALS AND METHODS}

\section{Viruses}

The M5C virulent strain was initially isolated from an outbreak of TGE in a local swine herd (Miller). It has been maintained by 5 serial passages in gnotobiotic pigs ${ }^{16}$ and represents an intestinal suspension of the fifth passage in gnotobiotic pigs. The M6 virulent TGEV represents a plaque purified low cell-culture passage (6 times) of the Miller virulent strain of TGEV in swine testicular (ST) cells ${ }^{16,22}$. The virus has retained its pathogenicity in gnotobiotic pigs (L.J. Saif, unpublished). The M60 Miller strain TGEV was passaged 60 times in ST cells ${ }^{23}$ and has low pathogenicity for gnotobiotic pigs compared to the M5C and M6 strains (L. J. Saif, unpublished).

Nine field isolates of TGEV designated S387, T184, T232, T507, T517, T876, T988, U328, and Zy were described ${ }^{12}$. These viruses were obtained from Ohio, Canada, Nebraska, South Dakota, and Michigan (Table 1). Each isolate was obtained from swine with clinical signs of TGE and TGEV-positive immunofluorescence staining on gut tissue samples. The isolates which were confirmed to be virulent by passage in susceptible pigs include S387, T232, T876, U328, and Zy.

The ISU-1 (Ind/89) and ISU-3 (NC/89) strains of PRCV provided by Dr. H. Hill, Iowa State Univ., Ames, Iowa ${ }^{24}$ were plaque-purified twice and passaged 8-14 times in ST cells. These viruses produce only subclinical infections when inoculated into gnotobiotic or conventional pigs and replicate exclusively in the upper respiratory $\operatorname{tract}^{21,25}$. The PRCV strain designated DD312 was recently isolated from the respiratory tract of a pig in the United States (Saif, Weilnau and Gadfield, unpublished).

\section{Monoclonal Antibodies (MAbs)}

TGEV-specific MAbs were produced and characterized in our laboratory ${ }^{12,13,14,15}$,

${ }^{16}$. These include neutralizing MAbs to sites $\mathrm{A}, \mathrm{B}$, and $\mathrm{E}$ of the $\mathrm{S}$ glycoprotein conserved on 
Table 1. Isolation and passage history of porcine coronaviruses used in this study ${ }^{12}$

\begin{tabular}{|c|c|c|c|c|c|}
\hline \multirow[b]{2}{*}{ Isolate } & \multirow[b]{2}{*}{ Virulence $^{\mathrm{a}}$} & \multicolumn{2}{|c|}{ Isolated } & \multirow[b]{2}{*}{$\mathrm{P \# (PP)b}$} & \multirow[b]{2}{*}{ Source } \\
\hline & & Data & State & & \\
\hline \multicolumn{6}{|c|}{ Reference Strains } \\
\hline M5C Miller & Virulent & 1965 & Ohio & $2(2)$ & E Bohl, OARDC, Wooster, OH \\
\hline M6 Miller & Virulent & 1965 & Ohio & $6(2)$ & L Salf, OARDC, Wooster, OH \\
\hline M60 Miller & Attenuated & 1987 & Ohio & $60(2)$ & R Woods, USDA Ames, Iowa \\
\hline W184 Purdue & Virulent & 1952 & Indiana & $4(1)$ & $\begin{array}{l}\text { E Haelterman, Purdue Unıv Purdue, } \\
\text { Indıana }\end{array}$ \\
\hline P115 Purdue & Attenuated & 1965 & Ohio & $>115^{\mathrm{c}}$ & E Bohl, OARDC, Wooster, Oh1o \\
\hline CC 1861 & Attenuated & 1972 & Nebraska & $?$ & M Welter, Ambico Vaccine Straın \\
\hline \multicolumn{6}{|c|}{ TGEV Fleld Strains ${ }^{\mathrm{d}}$} \\
\hline S387 & Virulent & 1987 & Ohio & $3(0)$ & NG Herd, Bucyrus, Ohıo \\
\hline T184 & $?$ & 1988 & Canada & $3(0)$ & $\begin{array}{l}\text { PS Carman, Ontarıo Mınıstry of } \\
\text { Agriculture and Food, Guelph, Ontarıo }\end{array}$ \\
\hline $\mathrm{T} 232$ & Virulent & 1988 & Ohio & $6(0)$ & OARDC Swine Center, Wooster, Ohıo \\
\hline T507 & $?$ & 1988 & Nebraska & $3(0)$ & R Moxley, Unıv Nebraska \\
\hline T517 & $?$ & 1988 & Nebraska & $6(0)$ & R Moxley, Unıv Nebraska \\
\hline T876 & Virulent & 1988 & Ohio & $3(0)$ & FF Herd, Wauseon, Ohio \\
\hline T988 & $?$ & 1987 & S Dakota & $2(0)$ & D Benfield, S Dakota State Unıv \\
\hline U327 & Virulent & 1989 & Michigan & $6(0)$ & R Macs, Michıgan State Unıv \\
\hline Zy & Virulent & 1986 & Ohio & $6(0)$ & Zy Herd, Burbank, Ohıo \\
\hline \multicolumn{6}{|l|}{ PRCV Strains } \\
\hline ISU-1 & & 1990 & Indiana & $8(2)$ & H Hill, Iowa State Unıv \\
\hline ISU-3 & & 1990 & N Carolına & $6(2)$ & H Hıll, Iowa State Unıv \\
\hline DD312 & & 1994 & Illınows & $4(0)$ & L Saif, OARDC, Wooster, Ohio \\
\hline
\end{tabular}

${ }^{a}$ Virulent $=$ enteropathogenıc, Attenuated = not enteropathogenıc $?=$ pathogenicity was not confirmed although virus was isolated from a diarrheic pig from a typical TGE outbreak The virulence was determined by passage in susceptable or gnotobiotic pigs

${ }^{b}$ Number of times passaged in cell culture (Number of times plaque-purified) ? indicates the passage number in cell culture and the number of times the virus was plaque purifed is unknown

${ }^{c}$ P115 was plaque purified numerous times during passage in cell culture

${ }^{\mathrm{d}}$ All field strains of TGEV were isolated from pigs with transmissible gastroenteritis confirmed using an immunofluoresence assay on intestınal samples

all strains of TGEV and PRCV tested and non-neutralızing MAbs (44C11 and 45A8) to site D of the S glycoprotein, reactive with TGEV strains but non-reactive with PRCV strains ${ }^{12}$ Other non-neutralızing MAbs to the S glycoprotein include 11H8, 8G11 and 75B10 The latter two react with site $\mathrm{V}$, conserved on Miller but not Purdue strains ${ }^{12}$

\section{Reverse Transcriptase/Polymerase Chain Reaction-Restriction Fragment Length Polymorphism (RT/PCR-RFLP) Assay}

Viral RNA was extracted and purified using proteinase K, acid phenol and the RNaid kit (BIO 101, La Jolla, CA) Briefly, ST cell culture solutions inoculated with the appropriate viruses were incubated for 5 minutes at $55^{\circ} \mathrm{C}$ in a solution containıng $2 \%$ SDS and $250 \mu \mathrm{g} / \mathrm{ml}$ proteinase $\mathrm{K}$ Following incubation the samples were extracted with acid phenol and chloroform/1soamyl alcohol The RNaid kit was used to purify viral RNA according to the manufacturers instructions Purified RNA was suspended in diethyl-pyrocarbonate (DEPC) treated water and stored at $-70^{\circ} \mathrm{C}$ before use in the reverse transcriptase (RT) reaction 


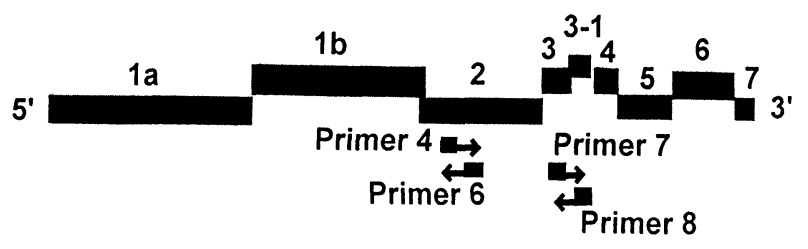

Figure 1. Schematic representation of the RNA genome of TGEV Miller strain, showing the location of the primers used for PCR. Primer set 4/6 amplifies a fragment of the S gene and primer set 7/8 amplifies RNAs 3 and $3-1$.

The nucleotide sequences of the oligonucleotide primers were deduced and synthesized according to the published TGEV Miller strain sequence. The locations of primers used in this study are shown in Figure 1.

The RT reaction contained $2 \mu$ of 10 X PCR buffer $(500 \mathrm{mM} \mathrm{KCl}, 200 \mathrm{mM}$ Tris, $\mathrm{pH}$ $8.4,0.5 \mathrm{mg} / \mathrm{ml}$ nuclease-free bovine serum albumin), $2 \mu \mathrm{l}$ of $10 \mathrm{mM}$ each dNTP, $250 \mathrm{ng}$ antisense primer, 40 units RNasin, $1.5 \mu \mathrm{l}$ of $60 \mathrm{mM} \mathrm{MgCl}_{2}$, and 3-5 $\mu \mathrm{l}$ of the purified viral RNA described above. A $20 \mu \mathrm{l}$ total reaction volume was obtained by adding sterile DEPC-treated water. The reaction mixture was heated at $65^{\circ} \mathrm{C}$ for 10 minutes before 200 units of Moloney murine leukemia virus RT was added. The reaction was then incubated for 1 hour at $45^{\circ} \mathrm{C}$. Following incubation, the reaction was stopped by heating to $95^{\circ} \mathrm{C}$ for 5 minutes.

The PCR reaction contained $8 \mu \mathrm{l}$ of $10 \mathrm{X}$ PCR buffer, $250 \mathrm{ng}$ of the sense primer, 3.5 $\mu \mathrm{l}$ of $60 \mathrm{mM} \mathrm{MgCl}_{2}$, and 2.5 units of Taq DNA polymerase. A $100 \mu \mathrm{l}$ total reaction volume was obtained by adding sterile distilled water. Thirty-five cycles of denaturation at $94^{\circ} \mathrm{C}$ for 1 minute, annealing at $45^{\circ} \mathrm{C}$ for 2 minutes, and polymerization at $74^{\circ} \mathrm{C}$ for 5 minutes were conducted. The initial denaturation and polymerization steps were at $94^{\circ} \mathrm{C}$ for 5 minutes and $74^{\circ} \mathrm{C}$ for 6 minutes, respectively. The final polymerization step was conducted at $74^{\circ} \mathrm{C}$ for 10 minutes. The PCR products were analyzed on a $1 \%$ agarose gel containing ethidium bromide.

In most cases it was not necessary to gel purify PCR products before conducting the $\mathrm{RE}$ analysis. However, depending on the restriction enzyme used, purification was sometimes necessary. The total PCR reaction product was separated on a $1 \%$ agarose gel. The amplified DNA with the appropriate size was cut from the gel and purified using the Geneclean kit (Bio 101) according to the manufacturer's recommendation. The purified DNA was digested with selected REs according to the manufacturer's specification. The restriction fragment patterns were observed following electrophoresis on a $2 \%$ agarose gel.

\section{RESULTS AND DISCUSSION}

The TGEV primer pair 4/6 amplified a portion of the $\mathrm{S}$ glycoprotein gene which was approximately $1.5 \mathrm{~kb}$. The size of the fragments from all TGEV and PRCV strains was similar indicating no major deletions or insertions. Using $S s p$ I to digest the PCR products amplified with primer pair 4/6 produced two RFLP patterns. Similar results were obtained using the enzyme DdeI. TGEV strains were placed into two groups using these enzymes. The first group was characterized by the Miller strain viruses and the second group by the Purdue strain viruses. When the enzyme Sau3AI was used, the viruses were placed into five groups (Table 2). Group 1 contained the Miller strain viruses and the PRCV strain DD312. The P115 Purdue strain, two TGEV field strains and the Ambico vaccine strain all contained similar RFLP patterns and were placed in group 2. Group 3 contained TGEV field strains and group 
Table 2. Correlation of the RT/PCR-RFLP results using primer pair 4/6 and Sau3AI enzyme with the ELISA and CCIF results using monoclonal antibodies (MAb) previously described $^{12}$

\begin{tabular}{|c|c|c|}
\hline Sau3AI Groups & Viruses & MAb Defined ${ }^{\mathrm{a}}$ Antigenic Groups \\
\hline \multirow[t]{4}{*}{1} & Miller (M6), Miller (M5C) & 8G11 Binding (Miller specific) \\
\hline & PRCV (DD312) ${ }^{\mathrm{b}}$ & 75B10 Binding \\
\hline & & $11 \mathrm{H} 8$ Binding \\
\hline & & 45A $8 / 44 \mathrm{C} 11$ Binding \\
\hline \multirow[t]{4}{*}{2} & Purdue (P115), & 8G11 Non-binding \\
\hline & TGEV Field Isolates: (T876, Zy) & 75B10 Non-binding \\
\hline & Ambico strain $(\mathrm{CC} 1861)$ & 11H8 Non-binding \\
\hline & & 45A8/44C11 Binding \\
\hline \multirow[t]{4}{*}{3} & TGEV Field Isolates: (S387, T232, & 8G11 Non-binding \\
\hline & T507, T517, U328, T988, CC717) & 75B 10 Non-binding (except U328) \\
\hline & & 11H8 Binding (except U328) \\
\hline & & 45A $8 / 44 \mathrm{C} 11$ Binding \\
\hline \multirow[t]{4}{*}{4} & TGEV Field Isolates: (T184, W184) & 8G11 Weak Binding \\
\hline & & 75B10 Non-binding \\
\hline & & 11H8 Weak Binding \\
\hline & & 45A $8 / 44 \mathrm{C} 11$ Binding \\
\hline \multirow[t]{4}{*}{5} & PRCV (ISU-1, ISU-3) & 8G11 Non-binding \\
\hline & & 75B 10 Non-binding \\
\hline & & $11 \mathrm{H} 8$ Binding \\
\hline & & 45A8/44C11 Non-binding \\
\hline
\end{tabular}

${ }^{a}$ Monoclonal antibodies (MAbs) were generated to the S glycoprotein of the virulent Miller TGEV strain and used to characterize viruses in ELISA and cell culture immunofluorescence assays ${ }^{12}$.

${ }^{b}$ The PRCV strain DD312 has not been thoroughly tested with the MAbs listed.

4 contained the virulent Purdue strain (W184) and a field isolate from Canada (T184). Group 5 contained the two Indiana PRCV strains ISU-1 and ISU-3.

The five Sau3AI groups could not be correlated with virulence of the TGEV isolates because confirmed virulent and attenuated viruses were observed in three of the four TGEV groups. The viruses tested appeared to fall into groups with similar origins. For example, the Miller strain viruses were grouped together, the Purdue origin vaccine strains were in a separate group and the PRCV strains were grouped together. There were two exceptions; the PRCV strain DD312 was grouped with the Miller strains and the virulent Purdue strain was placed in group 4 with a field isolate from Canada (T184).

Although the five RFLP groups defined by the enzyme Sau3AI did not correlate with pathogenicity or tissue tropism, they did correlate with antigenicity as defined using MAbs. In our previous studies, MAbs prepared to the Miller strain TGEV were used to differentiate five reference strains and nine field strains of TGEV ${ }^{12}$. The panel of MAbs used differentiated the viruses into seven distinctly different antigenic groups. Five of these MAb defined groups correlated with the five Sau3AI groups (Table 2). Although the DD312 PRCV strain was placed in group 1 with the Miller TGEV strains using RFLP, data on the MAb reactivity of this virus has not been completed.

The RFLP and MAb results ${ }^{12}$ indicated that strains of TGEV currently endemic in the U.S. are antigenically different from the Miller strain and Purdue strains of TGEV. The variability observed was in epitopes located on subsite $\mathrm{V}$ of the $\mathrm{S}$ glycoprotein gene ${ }^{12}$. 
The history of TGEV field isolates Zy and T876 is very interesting in the context of their RFLP (Sau3AI) and MAb (11H8, 8G11) assignment into a group with the Purdue attenuated TGEV strains These two virus isolates came from herds with a history of using commercial modified live TGEV vaccines (Ambico) However, the virulence of both strains has been confirmed by passage in gnotobiotic pigs

The region which spans RNA segments 3 and 3-1 was amplified using PCR primer pair 7/8 (Fig 1) The length of the 7/8 PCR products from PRCV strains was smaller than the TGEV strains with the one exception that the ISU-3 strain PCR product was similar in length to the Miller strain PCR product The virulent M6 Miller strain could be differentiated from the P115 strain because the M6 PCR product was 43 bases shorter than that observed for P115 (data not shown) The M60 strain did not amplify with the 7/8 primer pair due to a 531 base deletion in the 3-1 RNA region (data not shown) This region was reported to be important in defining the virulence of TGEV isolates $^{4}$ The NS3 open-reading-frame was non-functional in PRCV isolate $^{20}$ and an attenuated small plaque variant of the Miller TGEV suggesting a possible relationship with viral attenuation ${ }^{4}$ Our results using the Miller virulent and attenuated strains would indicate that differences in the size of the RNA 3 and 3-1 regions can be correlated with virulence and attenuation of these viruses

\section{REFERENCES}

1 Cubero M J, Bernard S, Leon L, Berthon P and Contreras A Pathogenicity and antigen detection of the nouzilly strain of transmissible gastroenteritıs coronavirus, in 1-week-old piglets $\mathrm{J}$ Comp Path 1994,106 61-73

2 Britton P, Kottier S, Chen C -M, Pocock D H, Salmon H, and Aynaud J M The use of PCR genome mapping for the characterısation of TGEV strains In Coronaviruses (H Laude, and J F Vautherot Eds ) Plenum Press, New York 1994 pp29-34

3 Saif L J and Wesley R Transmissible gastroenteritıs In Diseases of Swine Eds A D Leman, B Straw, R D Glock, W L Mengelıng, R H C Penny, and E Scholl Iowa State Unıv Press, Ames, Iowa 1992 pp 362-386

4 Wesley R D, Woods R D, and Cheung A K Genetıc basis for the pathogenesis of transmissible gastroenteritis virus $\mathrm{J}$ Virol 1990, 64 4761-4766

5 Enjuanes L, Sune C, Gebauer F, Smerdou C, Camacho A, Anton I M, Gonzalez S, Talamillo A , Mendez A, Ballesteros M L and Sanchez C Antigen selection and presentation to protect against transmissible gastroenteritıs coronavirus Vet Microbiol 1992,33 249-262

6 Gebauer F, Posthumus W P A , Correa I, Sune C, Smerdou C, Sanchez C M, Lenstra J A, Meloen $\mathrm{R} \mathrm{H}$, and Enjuanes L Residues involved in the antıgenıc sites of gastroenteritıs coronavirus S glycoprotein Virology 1991, 183 225-238

7 Sanchez, C M, Gebauer F, Sune C, Mendez A, Dopazo J, and Enjuanes L Genetic evolution and tropism of transmissible gastroenteritis coronavirus Virol 1992, 190 92-105

8 Callebaut P, Correa I, Pensaert M, Jimenez G, and Enjuanes L Antigenic differentiation between transmissible gastroenteritıs virus of swine and a related porcine respiratory coronavirus $J$ Gen Virol 1988,69 1725-1730

9 Delmas B , Gelfi J and Laude H Antıgenic structure of transmissible gastroenteritıs virus II Domains in the peplomer glycoprotein J Gen Virol 1986, 67 1405-1418

10 Diego M D , Laviada M D , Enjuanes L, and Escribano J M Epitope specificity of protective lactogenic immunity against swine transmissible gastroenteritis virus J Virology 1992, 66 6502-6508

11 Hodatsu T, Eiguchı Y, Tsuchımoto M, Ide S, Yamagıshı H, and Matumoto M Antigenıc Variation of Porcine Transmissible Gastroenteritıs Virus Detected by Monoclonal Antibodies Vet Microbiol 1987,14 115-124

12 Simkıns R A, Weilnau P A , Bias J , and Saif L J Antıgenıc varıation among transmissıble gastroenteritıs virus (TGEV) and porcine respiratory coronavirus (PRCV) strains detected with monoclonal antıbodies to the S protein of TGEV Am J Vet Res 1992,53 1253-1258

13 Simkıns R A, Weilnau P A, VanCott J, Brım T A , and Saif L J Competition ELISA, using monoclonal antıbodies to the transmissible gastroenteritis virus (TGEV) S protein, for serologic differentiation of pigs infected with TGEV or porcine respiratory coronavirus Am J Vet Res 1993,54 254-259 
14 Simkıns R A, Saif L J , and Weılnau P A Epıtope mappıng and detection of transmıssıble gastroenteritıs viral proteins in cell culture using biotınylated monoclonal antıbodies in a fixed-cell ELISA Arch Virol 1989,107 179-190

15 Welch, S K W and Saif L J Production and characterization of monoclonal antibodies to transmissible gastroenteritıs virus of pıgs (Abstract) 67th Ann Mtg Conf Res Workers in Anımal Disease, $1986 \mathrm{pp} 9$

16 Welch, S K W and Saif L J Monoclonal Antibodies to a Virulent Strain of Transmissible Gastroenteritis Virus Comparison of Reactivity Against the Attenuated and Virulent Virus Strains Arch Virol $1988,102221-236$

17 Enjuanes L , Sanchez C Gebauer F, Mendez A, Dopazo J , and Ballesteros M L Evolution and tropısm of transmissible gastroenteritis coronavirus In Coronaviruses ( $\mathrm{H}$ Laude, and $\mathrm{J} F$ Vautherot Eds ) Plenum Press, New York 1994 pp35-42

18 O'Toole D, Brown I, Bridges A, and Cartwright S F Pathogenicity of experimental infection with pneumotropic procine coronavirus Res Vet Sc1 1989,47 23-29

19 Pensaert M B, Caıllebaut $\mathrm{P}$, and Vergote J Isolation of a new porcine respiratory, nonenteric coronavirus related to transmissible gastroenteritis Vet Q , 1986, 8 257-261

20 Rasschaert D, Duarte M, and Laude H Porcine respiratory coronavırus differs from transmissible gastroenteritis virus by a few genomic deletions J Gen Vırol 1990,71 2599-2607

21 Wesley R D, Woods R D, Hill H T, Biwer J D Evidence for a procine respiratory coronavirus, antigenically similar to transmissible gastroenteritıs virus, in the United States $\mathrm{J}$ Vet Diagn Invest 1990,2 312-317

22 Bohl, E H and Saif L J Passive immunity in transmissible gastroenteritis of swine immunoglobulin characteristics of antibodies in milk after inoculating virus by different routes Infect Immunol 1975,11 23-31

23 Woods R D Humoral and cellular responses in swine exposed to transmissible gastroenteritis virus Am J Vet Res 1979, 40 108-110

24 Hill H, Biwer J, Wesley R D, and Woods R D Porcine respiratory coronavirus in the United States Abstr 70th Conf Res Workers in Animal Dis 1989, (242)

25 VanCott J L, Brım T A, Simkıns R A, and Saif L J Isotype-specific antıbody secretıng cells to transmissible gastroenteritıs virus and porcine respiratory coronavirus in gut- and bronchus-associated lymphoid tissues of suckling pigs J Immunol 1993,3990-4000 